\title{
Determinants of Environmental Sanitation Related to the Incidence of Diarrhea among Infants
}

\author{
Jernita Sinaga ${ }^{1 *}$, Risnawati Tanjung ${ }^{2}$, Eka Lestari Mahyuni ${ }^{3}$, Helfi Nolia ${ }^{4}$, and Raflizar ${ }^{5}$ \\ ${ }^{1,2,4}$ Department of Environmental Health, Health Polytechnic of the Ministry of Health Medan, \\ Indonesia \\ ${ }^{3}$ Department of Occupational Safety and Health, Faculty of Public Health, Universitas Sumatera \\ Utara, Medan, Indonesia \\ ${ }^{5}$ Puslitbang Public Health Efforts, Ministry of Health RI Research and Development Agency, \\ Indonesia \\ *corresponding author, e-mail: jernitasinaga_74@yahoo.co.id
}

\section{ARTICLE INFO}

Article history

Received 7/2/2021

Revised 8/26/2021

Accepted 2/9/2021

Keywords

Environmental sanitation; Diarrhea;

Infant

\section{ABSTRACT}

Background: Incidence of diarrhea increased by poor environmental conditions factors. The several factors of environmental health are housing, disposal waste, clean water supply, and sewerage. This study's purpose was to determine the determinants of environmental sanitation related to the incidence of diarrhea in infants at the work area of Pusat Kesehatan Masyarakat (Puskesmas) Singa, Karo District. Method: This research was quantitative research as a case study of diarrhea among infants in Puskesmas Singa. The subjects were housewives who had infants and suffered from diarrhea in the last six months of the study, with 225 total population and 63 people selected by simple random sampling. The data analyzed used logistic regression to found the influence of environmental sanitation on diarrhea. Results: The results found there were six variables analyzed, there were three variables that influenced the incidence of diarrhea, the variable ownership of feces disposal facilities was the most dominant factor with Exp B 18.267 (p-value 0.003; 95\% Cl: 2.750-121.334), and the quality of clean water are variables that influence the incidence of diarrhea with Exp B 5.763 (p-value 0.026; 95\% Cl: 1.234-26.904), food and drink sanitation are variables that influence the incidence of diarrhea with Exp B 12.451 ( $p$-value 0.004; 95\% Cl: 2.190 70.773). Conclusion: It concludes that diarrhea among infants has a dominant relationship of water sanitation, disposal sanitation, and food sanitation as determinants. It needs to improve basic sanitation to decrease the count of diarrhea.

This is an open access article under the CC-BY-SA license.

\section{Introduction}

Diarrhea is a world public health problem, especially in developing countries. Diarrhea disease is transmitted through water, where clean water sources are still a top priority issue in the Pacific region, including Indonesia. The percentage of deaths caused by diarrhea in children under five years of age increased by approximately $8 \%$ of all death. It means over 1,400 young children dying each day, or about 525,000 children a year, despite the availability of a simple treatment solution. Diarrhea is also one of the environmental diseases and is predominantly caused by poor clean water facilities, disposal of feces and waste. Lack of clean water coverage is one of the factors in the incidence of diarrhea disease and needs to be considered because water is a necessity for bathing, washing, latrines, and consumption which must be protected and have to meet the water contaminated requirements [1-4]. 
Based on various studies, eight percent of deaths in children are caused by diarrhea [5]. The leading causes of diarrhea are dominated by environmental sanitation and poor sanitary behavior. Various factors as the cause of diarrhea, including poor knowledge of mothers, bad handwashing behavior, poor nutritional status, clean water supply, family latrines, wastewater disposal family waste disposal, water physical quality, type of house floor, the behavior of clean and healthy life, lack of food sanitation, exclusive breastfeeding and immunization, socio-economic factors, knowledge, and level of parental care [6-14]. The target of national service coverage for diarrhea sufferers for children under five who come to health facilities and health care is $37.88 \%$. The national diarrhea incidence from Riset Kesehatan Dasar (Riskesdas) data is $9 \%$. It is estimated that the number of diarrhea sufferers in health facilities is $5,097,247$ people, while the number of diarrhea sufferers reported being handled in health facilities is $4,017,861$ people or $74.33 \%$ of the target of 5,405,235 [15-17].

The estimated number of diarrhea cases was 614 cases $(20 \% \times 270 / 1,000 \times$ Population number), which were found and handled as many as $389(63.3 \%)$ so that the diarrhea morbidity per 1,000 population only reached 156 still below the program target of 270 per 1,000 population. It is feared that the low morbidity rate is not a reflection of a decrease in the incidence of diarrhea in the community but more due to the large number of cases that are not recorded (under-reporting cases). The highest case was finding at nineteen health centers in which handling of diarrhea was dominant in three health centers, namely Tiganderket (96.04\%), Munte (83.88\%), and Singa $(80.95 \%)$. Meanwhile, the lowest case finding and handling of diarrhea were in Tigapanah, Simpang Empat, Naman Teran, and Payung, respectively [18].

Diarrhea cases always occupy the top of ten diseases every month at Pusat Kesehatan Masyarakat (Puskesmas) Singa (80.95\%) and including the highest area of diarrhea sufferers in Karo District [18]. The high incidence of diarrhea at Puskesmas Singa, located in Kabanjahe District, Karo Regency, is a health problem that needs attention. Therefore, this study aimed to analyze the determinants of environmental sanitation with the incidence of diarrhea in the infant at the work area of Puskesmas Singa. Environmental sanitation aspects reviewed include the physical and bacteriological quality of clean water, drinking water sources, latrine ownership, feces disposal facilities, waste disposal facilities, and food and beverage sanitation.

\section{Materials and Method}

This research was quantitative research with a case study design of the incidence of infant diarrhea in the Puskesmas Singa working area in a cross-sectional approach. The research location was carried out in the home environment of infants who experienced diarrhea in the last six months of March to August 2020. The population of infants who live in the working area of Puskesmas Singa is 255 , with sample size, are 63 infants. The sampling technique used in this study was Simple Random Sampling.

The data collection method was carried out by observing environmental conditions and interviews. Objects directly observed included drinking water sources, physical quality of clean water, ownership of latrines, waste processing, wastewater treatment, and food sanitation. The research instruments used were questionnaires, checklist sheets, and bacteriological examination equipment. This research also used the Karo District environmental health laboratory services to support accurate sanitation checks. The data analysis technique used multiple logistic regression tests by using SPSS version 25.0 .

\section{Results and Discussion}

\subsection{Results}

The Puskesmas Singa, Tiga Panah District, is an essential health facility for the Karo Regency government with eight villages and one hamlet. There are five supporting public health centers, three maternity houses/independent midwife practice, and three Poskesdas. Based on the case study conducted, the incidence of diarrhea in infants was experienced as many as 40 incidents $(63.5 \%)$, which was dominated by children aged two years $(50 \%)$ with female gender $(61.9 \%)$ (Table 1). The observations show that the environmental sanitation conditions in the Puskesmas Singa community are pretty bad (Figure 1). Although this village is a mountainous area, based on a bacteriological examination of the water, it was found that 220 drilled well water sources did not meet health requirements. In general, people buy water, and retail it is distributed through water entrepreneurs. Only some people use tap water to meet their daily needs (Table 2). Poor environmental sanitation in this community is related to the health behavior of the community. People did not care about their sanitation and only focused on how to being live with their occupation. Based on the interview, the community feels enough about their condition and 
keeps healthy otherwise. They could be to work daily. Most of the houses did not have a disposal waste place and poor housing with bad disposal management. All water sources found $E$. coli and bacteriology and did not fulfill the health requirement. It is found in the bore wells, the river, public reservoirs, and home water sources.

Table 1. Characteristic of Respondents

\begin{tabular}{ccc}
\hline Variable & $\mathbf{n}$ & $\%$ \\
\hline $\begin{array}{l}\text { Diarrhea incidence } \\
\text { Diarrhea }\end{array}$ & 40 & 63.5 \\
$\quad$ No diarrhea & 23 & 36.5 \\
$\begin{array}{l}\text { Infant Sex } \\
\text { Male }\end{array}$ & 24 & 38.1 \\
$\quad$ Female & 39 & 61.9 \\
Infant Age & & \\
2 years & 31 & 50 \\
3-4 years & 25 & 40 \\
5 years & 7 & 10 \\
\hline
\end{tabular}
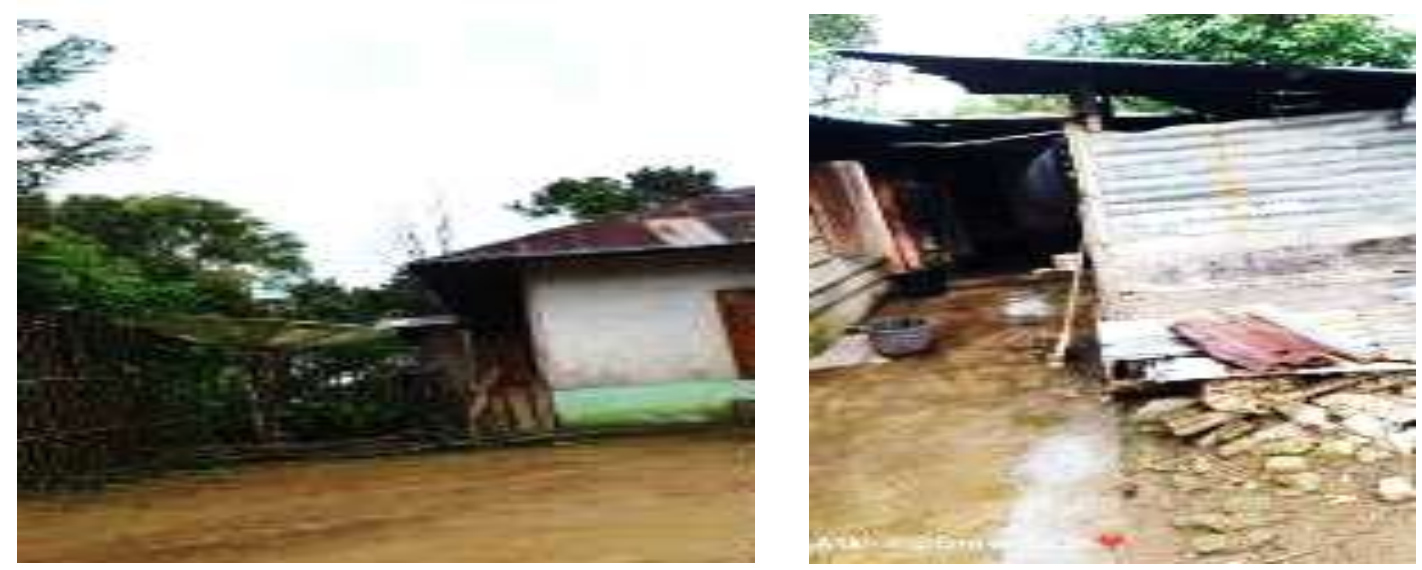

Figure 1. Sanitation Environment of Community Condition

Table 2. Frequency Distribution of Environment Sanitation

\begin{tabular}{lcc}
\hline \multicolumn{1}{c}{ Variable } & N & $\%$ \\
\hline Source of Drinking Water & & \\
Open water well & 6 & 9.5 \\
Tap water/dilute/buy & 32 & 50.8 \\
General pet & 9 & 14.3 \\
Refill water & 11 & 17.5 \\
$\quad$ Closed borehole & 5 & 7.9 \\
Source of clean drinking water & & \\
Open water well & 12 & 19.0 \\
Tap water/dilute/buy & 35 & 55.6 \\
General pet & 14 & 22.2 \\
Refill water & 2 & 3.2 \\
\hline
\end{tabular}

The incidence of diarrhea determinants in infants is caused by poor drinking water, feces disposal facilities and food, and beverage sanitation. Other factors that support the potential for diarrhea are the poor physical quality of the water, inadequate waste disposal facilities, and wastewater. The facilities owned by the community are elementary and do not meet the recommended requirements. Besides that, the clean behavior of the community is also fragile considering that the majority of people are farming and rarely pay attention to the cleanliness of the food and drink that they consume (Figure 2). 


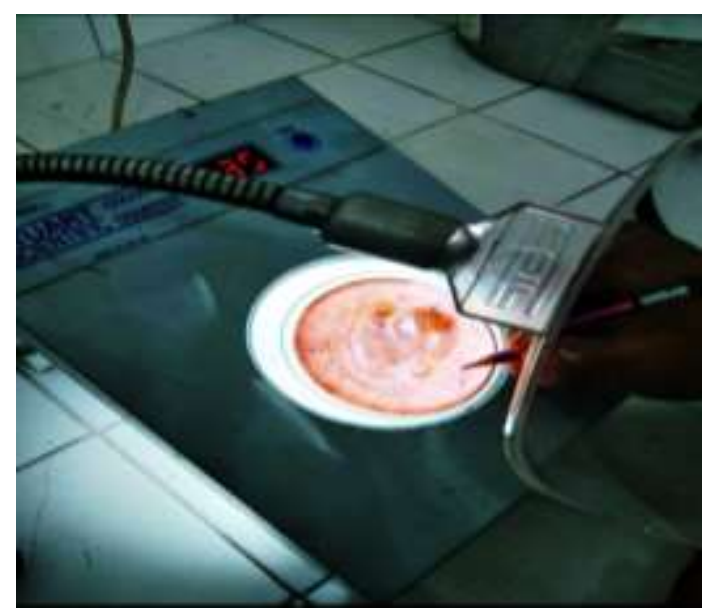

Figure 2. Germ Colony Inspection Results

Food and drink sanitation and disposal of feces are mostly about diarrhea. It showed that the poor health life being among community needed to attention where the community did not care about the sanitation. This problem triggers the potential for diarrhea in infants or toddlers and adults and society in general (Table 3). The variable ownership of feces disposal facilities is the most dominant factor with Exp B 18.267 (95\% Cl: 2.750-121.334;p<0.05), food and drinks sanitation are variables that affect the incidence of diarrhea with Exp B 12.451 (95\% Cl: 2.190 70.773; $p<0.05)$, and the quality of clean water is a variable that affects the incidence of diarrhea with Exp B 5.763 (95\% Cl: 1.234 - 26.904; p<0.05). More details can be seen in Table 3.

Table 3. Bivariate Analysis Results

\begin{tabular}{|c|c|c|c|c|c|c|}
\hline \multirow{3}{*}{ Variable } & \multicolumn{4}{|c|}{ Diarrhea } & \multirow{3}{*}{ P-value } & \multirow{3}{*}{$\begin{array}{l}\text { OR }(95 \% \mathrm{Cl}) \\
\operatorname{Exp}(\mathrm{B})\end{array}$} \\
\hline & \multicolumn{2}{|c|}{ Yes } & \multicolumn{2}{|c|}{ No } & & \\
\hline & $\mathbf{n}$ & $\%$ & $\mathbf{n}$ & $\%$ & & \\
\hline \multicolumn{7}{|c|}{ Physical Quality of Water } \\
\hline Not eligible & 27 & 81.8 & 6 & 18.2 & \multirow{2}{*}{0.004} & \multirow{2}{*}{$\begin{array}{c}5.88 \\
(1.87-18.43) \\
(1.234-26.904)\end{array}$} \\
\hline Eligible & 13 & 43.3 & 17 & 56.7 & & \\
\hline \multicolumn{7}{|l|}{$\begin{array}{l}\text { Ownership of Waste } \\
\text { Disposal Facilities }\end{array}$} \\
\hline Have & 30 & 66.7 & 15 & 33.3 & \multirow[t]{2}{*}{0.289} & 1.60 \\
\hline Do Not Have & 10 & 56.6 & 8 & 44.4 & & $(0.523-4.891)$ \\
\hline \multicolumn{7}{|c|}{$\begin{array}{l}\text { Ownership of Disposing } \\
\text { Feces }\end{array}$} \\
\hline Have & 23 & 88.5 & 3 & 11.5 & \multirow[t]{2}{*}{0.001} & \multirow{2}{*}{$\begin{array}{c}9.02 \\
(2.031-35.34) \\
(2.750-121.334)\end{array}$} \\
\hline Do Not Have & 17 & 45.9 & 20 & 54.1 & & \\
\hline \multicolumn{7}{|c|}{$\begin{array}{l}\text { Ownership of Water Waste } \\
\text { Disposal Facilities }\end{array}$} \\
\hline SPAL Bad & 38 & 67.9 & 18 & 32.1 & \multirow[t]{2}{*}{0.105} & \multirow{2}{*}{$\begin{array}{c}5.27 \\
(0.933-29.862)\end{array}$} \\
\hline \multicolumn{5}{|l|}{$\begin{array}{l}\text { Food and beverage } \\
\text { Sanitation }\end{array}$} & & \\
\hline $\mathrm{Bad}$ & 36 & 80.0 & 9 & 20.0 & \multirow[t]{2}{*}{0.000} & \multirow{2}{*}{$\begin{array}{c}14.0 \\
(3.704-52.922) \\
(2.190-70.773)\end{array}$} \\
\hline Good & 4 & 22.2 & 14 & 77.8 & & \\
\hline
\end{tabular}

\subsection{Discussion}


Environmental sanitation determinants that affect the incidence of diarrhea in the infant at Singa Village are inadequate sanitation facilities in waste disposal facilities, clean water facilities, wastewater facilities, and poor food and beverage sanitation. Based on the logistic regression model obtained shows that three important determinants dominate the incidence of diarrhea.

\subsubsection{Determinant of drinking water}

The community for drinking water in Singa Village generally uses drilled wells. This case shows that drinking water quality needs to be considered a requirement for recommended drinking water facilities. This study focuses on water from springs, drilled wells directly at home, and wells through the reservoir used. Most of the people with the physical quality of drinking water that does not meet the requirements. The incidence of diarrhea is related to the bacteriological condition of the source of drinking water consumed. Various studies have shown that the physical quality of water is a very significant determinant of the incidence of diarrhea $[8,9,19-21]$.

Communities can reduce the risk of developing diarrhea by using clean water and water protected from contamination from source to storage. Therefore, it is necessary to increase the socialization and supervision of health workers and cooperation between the village head and the Puskesmas Singa to conduct sanitation inspections of clean water facilities and counsel the community to pay attention to the water sources used. Clean water is used to be protected from contamination, namely keeping wells clean by improving construction and keeping well buildings, pipelines, and storage areas clean [3,22-24].

\subsubsection{Determinant of feces disposal}

Facilities for disposing of feces are a determinant that affects the incidence of diarrhea 9.020 times greater in people who do not have a means of disposing of feces that meet the requirements. From the results of multivariate analysis using logistic regression, it was found that the variable ownership of feces disposal facilities was the most dominant factor. This determinant is the trigger because of the poor facilities for disposing of feces in Singa village communities. Some residents use clean water from drilled wells and have toilets (family latrines) in their homes that do not meet environmental health requirements. This facility is at risk of causing microbiological pollution, and a safe distance between the walls of the wells and sources of pollution should be 10 meters. However, on average, residents are located directly next to a drilled well to pollute the well-water used as a water source. Exposure through feces can also occur through water contamination (water-borne disease) or orally (food-borne disease). Most likely, this is due to inadequate hygiene and healthy living habits. This determinant is also closely related to the habit of washing hands to avoid contamination with feces. Therefore, fecal sanitation, either through disposal or contamination through the quality of drinking water and food, is the highest determining factor affecting the incidence of diarrhea in children under five (infant) [3,24-28].

\subsubsection{Determinant Food and beverage sanitation}

Nutritional status, microbiology, and immunological factors have implications for the incidence of diarrhea in several countries. Food and beverage sanitation determinants influence the incidence of diarrhea in children under five, supported by poor environmental sanitation and personal hygiene [29].

The incidence of diarrhea on food and beverage sanitation risk factors can be concluded that the incidence of diarrhea will be 14 times greater in people whose food and drink sanitation is poor, and it is practically and statistically significant. In general, this determinant is related to the bad behavior of washing hands with soap. The habit of this behavior can lead to contamination of food and beverages. This behavior requires knowledge of the risk factors for the incidence of diarrhea. Public ignorance of the risk of diarrhea, determined by clean behavior and good basic sanitation, is often the cause of the incidence of diarrhea. In this case, mothers' knowledge and attitudes have a significant role in the incidence of diarrhea in children under five. Clean water sources also affect the cleanliness of the eating and drinking utensils used. If the clean water source is contaminated with pathogenic bacteria such as E. coli, eating and drinking utensils are at risk, especially if the washing behavior is not good [30-35].

Food sanitation is one of the people's behavior to prevent freeing food from all dangers that can interfere with health, from before processing to consumption, even how to handle it afterward, such as being stored in a safe place. Most people have stored processed food in a good place from the research results, such as in a closed cupboard/refrigerator. However, it is 
also found that people store food on the table when it is open. Open cupboards without a cover are still not good enough to choose only to store processed food on the floor and open and in a cupboard that is not closed. Storing food without a cover will result in the food being contaminated with the growth of microorganisms, which plays a vital role in forming compounds that produce unpleasant odors and cause food to become unfit for eating. Some microorganisms that contaminate food can pose a danger to those who consume it.

\section{Conclusion}

Based on the results of research conducted in the area of the Singa Village, it can be concluded that the dominant determinants affecting the incidence of diarrhea in the infant are clean water facilities, including the physical quality of water, feces disposal facilities, and food and beverage sanitation. It suggested increasing physical water sanitation and microbiology. Water closed facility and healthy food by developing high personal hygiene in communities.

\section{Declaration}

Acknowledgments: The authors are very thankful to the Director of Polytechnic Health Ministry Medan for funding this research with contract number 024.16/PPK/I-Poltekkes Medan/II/2020. This research has been completed in collaboration with Mr. Abel Ginting as leader of the village and Puskesmas Singa in a good relationship. Good sanitation could be integrated with good collaboration in this research, so we said thank you to all communities of Singa village that contributed to this research.

Conflicts of Interest: The author states that this study does not have a conflict of interest regarding the data and results of the research that has been done.

\section{References}

1. Galezzo, M. A., Günther, W., Diaz-Quijano, F. A., \& Susa, M. R. (2020). Factors Associated with Diarrheal Disease in the Rural Caribbean Region of Colombia. Revista de saude publica, 54, 90. https://doi.org/10.11606/s1518-8787.2020054002054

2. Oberhelman, R. A., Gilman, R. H., Sheen, P., Taylor, D. N., Black, R. E., Cabrera, L., Lescano, A. G., Meza, R., \& Madico, G. (1999). A Placebo-Controlled Trial of Lactobacillus GG to Prevent Diarrhea in Undernourished Peruvian Children. The Journal of pediatrics, 134(1), 15-20. https://doi.org/10.1016/s0022-3476(99)70366-5

3. Chard, A. N., Garn, J. V., Chang, H. H., Clasen, T., \& Freeman, M. C. (2019). Impact of a School-Based Water, Sanitation, and Hygiene Intervention on School Absence, Diarrhea, Respiratory Infection, and Soil-Transmitted Helminths: Results from the WASH HELPS Clusterrandomized Trial. Journal of global health, 9(2), 020402. https://doi.org/10.7189/jogh.09.020402

4. World Health Organization. MCEE-WHO methods and data sources for child causes of death 2000-2016 [Internet]. Geneva, Swiss; 2018. Available from: https://www.who.int/healthinfo/global_burden_disease/childcod_methods_2000_2016.pdf?ua= 1

5. Darvesh, N., Das, J. K., Vaivada, T., Gaffey, M. F., Rasanathan, K., Bhutta, Z. A., \& Social Determinants of Health Study Team (2017). Water, Sanitation and Hygiene Interventions for Acute Childhood Diarrhea: A Systematic Review to Provide Estimates for the Lives Saved Tool. BMC public health, 17(Suppl 4), 776. https://doi.org/10.1186/s12889-017-4746-1

6. Vieira, L. V., Pedrosa, L., Souza, V. S., Paula, C. A., \& Rocha, R. (2018). Incidence of Diarrhea and Associated Risk Factors in Patients with Traumatic Brain Injury and Enteral Nutrition. Metabolic brain disease, 33(5), 1755-1760. https://doi.org/10.1007/s11011-0180287-2

7. Noguchi, Y., Nonaka, D., Kounnavong, S., \& Kobayashi, J. (2021). Effects of Hand-Washing Facilities with Water and Soap on Diarrhea Incidence among Children under Five Years in Lao People's Democratic Republic: A Cross-Sectional Study. International journal of environmental research and public health, 18(2), 687. https://doi.org/10.3390/ijerph18020687

8. Contreras, J. D., \& Eisenberg, J. (2019). Does Basic Sanitation Prevent Diarrhea? Contextualizing Recent Intervention Trials through a Historical Lens. International journal of environmental research and public health, 17(1), 230. https://doi.org/10.3390/ijerph17010230

9. Freeman, M. C., Garn, J. V., Sclar, G. D., Boisson, S., Medlicott, K., Alexander, K. T., Penakalapati, G., Anderson, D., Mahtani, A. G., Grimes, J., Rehfuess, E. A., \& Clasen, T. F. (2017). The Impact of Sanitation on Infectious Disease and Nutritional Status: A Systematic 
Review and Meta-Analysis. International journal of hygiene and environmental health, 220(6), 928-949. https://doi.org/10.1016/j.ijheh.2017.05.007

10. Vilcins, D., Sly, P. D., \& Jagals, P. (2018). Environmental Risk Factors Associated with Child Stunting: A Systematic Review of the Literature. Annals of global health, 84(4), 551-562. https://doi.org/10.9204/aogh.2361

11. Wasihun, A. G., Dejene, T. A., Teferi, M., Marugán, J., Negash, L., Yemane, D., \& McGuigan, K. G. (2018). Risk Factors for Diarrhoea and Malnutrition Among Children Under the Age of 5 years in the Tigray Region of Northern Ethiopia. PloS one, 13(11), e0207743. https://doi.org/10.1371/journal.pone.0207743

12. Savaş Şen, Z., Taşar, M. A., Demirel Kaya, F., Güneş, A., Vezir, E., \& Hızarcıoğlu Gülşen, H. (2019). Akut Cryptosporidium İshalinin Nadir Bir Komplikasyonu: İmmün Yetmezlik Bulunmayan Çocuk Olguda Olası Hepatobiliyer Tutulum [A Rare Complication of Acute Diarrhae Caused by Cryptosporidium: Possible Hepatobiliary System Involvement in a Child without Immunodeficiency]. Mikrobiyoloji bulteni, 53(4), 464-471. https://doi.org/10.5578/mb.68508

13. Null, C., Stewart, C. P., Pickering, A. J., Dentz, H. N., Arnold, B. F., Arnold, C. D., BenjaminChung, J., Clasen, T., Dewey, K. G., Fernald, L., Hubbard, A. E., Kariger, P., Lin, A., Luby, S. P., Mertens, A., Njenga, S. M., Nyambane, G., Ram, P. K., \& Colford, J. M., Jr (2018). Effects of Water Quality, Sanitation, Handwashing, and Nutritional Interventions on Diarrhoea and Child Growth in Rural Kenya: A Cluster-Randomised Controlled Trial. The Lancet. Global health, 6(3), e316-e329. https://doi.org/10.1016/S2214-109X(18)30005-6

14. Zúñiga-brenes $P$. Factors Influencing the Occurrence of Diarrhoea Among Children Under the Age of Five Admitted to Benadir Hospital Mogadishu - Somalia. Jamhuriya. 2017;1:59. DOI: https://doi.org/10.5099/aj210200060

15. Troeger, C., Khalil, I. A., Rao, P. C., Cao, S., Blacker, B. F., Ahmed, T., Armah, G., Bines, J. E., Brewer, T. G., Colombara, D. V., Kang, G., Kirkpatrick, B. D., Kirkwood, C. D., Mwenda, J. M., Parashar, U. D., Petri, W. A., Jr, Riddle, M. S., Steele, A. D., Thompson, R. L., Walson, J. L., ... Reiner, R. C., Jr (2018). Rotavirus Vaccination and the Global Burden of Rotavirus Diarrhea Among Children Younger Than 5 Years. JAMA pediatrics, 172(10), 958-965. https://doi.org/10.1001/jamapediatrics.2018.1960

16. Woldeamanuel B. T. (2020). Trends and Factors Associated with Healthcare Utilization for Childhood Diarrhea and Fever in Ethiopia: Further Analysis of the Demographic and Health Surveys from 2000 to 2016. Journal of environmental and public health, 2020, 8076259. https://doi.org/10.1155/2020/8076259

17. Mbakaya, B. C., Lee, P. H., \& Lee, R. L. (2017). Hand Hygiene Intervention Strategies to Reduce Diarrhoea and Respiratory Infections among Schoolchildren in Developing Countries: A Systematic Review. International journal of environmental research and public health, 14(4), 371. https://doi.org/10.3390/ijerph14040371

18. Burns, D. S., Porter, C. K., Gutierrez, R. L., McDavid, N. C., Hutley, E. J., Riddle, M. S., \& Connor, P. (2020). Diarrhea and Associated Illness Characteristics and Risk Factors Among British Active Duty Service Members at Askari Storm Training Exercise, Nanyuki, Kenya, January-June 2014. MSMR, 27(8), 4-7.

19. Fang, X. Y., Liu, W. D., Ai, J., \& Bao, C. C. (2019). Zhonghua liu xing bing xue za zhi = Zhonghua liuxingbingxue zazhi, 40(10), 1269-1273. https://doi.org/10.3760/cma.j.issn.02546450.2019 .10 .018

20. Jung, Y. T., Lou, W., \& Cheng, Y. L. (2017). Exposure-Response Relationship of Neighbourhood Sanitation and Children's Diarrhoea. Tropical Medicine \& International Health: TM \& IH, 22(7), 857-865. https://doi.org/10.1111/tmi.12886

21. Adane, M., Mengistie, B., Kloos, H., Medhin, G., \& Mulat, W. (2017). Sanitation Facilities, Hygienic Conditions, and Prevalence of Acute Diarrhea Among Under-Five Children in Slums of Addis Ababa, Ethiopia: Baseline Survey of A Longitudinal Study. PloS one, 12(8), e0182783. https://doi.org/10.1371/journal.pone.0182783

22. Marniati M, Rahmayani R. Factors Affecting the Diarrhea Occurrences on U5 Children in Manyak Payed Public Health Services Aceh Tamiang. J Healthc Technol Med. 2017;1(1). DOI: https://doi.org/10.33143/jhtm.v1i1.13

23. Soboksa NE, Hailu AB, Gari SR, Alemu BM. Water Supply, Sanitation and Hygiene Interventions and Childhood Diarrhea In Kersa and Omo Nada Districts Of Jimma Zone, Ethiopia: A Comparative Cross-Sectional Study. J Health Popul Nutr. 2019;38(1):1-14. DOI: https://doi.org/10.1186/s41043-019-0205-1

24. Alemayehu M, Alemu T, Astatkie A. Prevalence and Determinants of Diarrhea among UnderFive Children in Benna Tsemay District, South Omo Zone, Southern Ethiopia: A Community- 
Based Cross-Sectional Study in Pastoralist and Agropastoralist Context. Adv Public Heal. 2020;2020:1-11. DOI: https://doi.org/10.1155/2020/4237368

25. Nasiatin, T., Pertiwi, W. E., Setyowati, D. L., \& Palutturi, S. (2021). The Roles of HealthPromoting Media in the Clean and Healthy Living Behavior of Elementary School Students. Gaceta sanitaria, 35 Suppl 1, S53-S55. https://doi.org/10.1016/j.gaceta.2020.12.015

26. Chen, J., Wan, C. M., Gong, S. T., Fang, F., Sun, M., Qian, Y., Huang, Y., Wang, B. X., Xu, C. D., Ye, L. Y., Dong, M., Jin, Y., Huang, Z. H., Wu, Q. B., Zhu, C. M., Fang, Y. H., Zhu, Q. R., \& Dong, Y. S. (2018). Chinese Clinical Practice Guidelines for Acute Infectious Diarrhea in Children. World Journal of Pediatrics : WJP, 14(5), 429-436. https://doi.org/10.1007/s12519018-0190-2

27. Paul P. (2020). Socio-demographic and Environmental Factors Associated with Diarrhoeal Disease Among Children Under Five in India. BMC public health, 20(1), 1886. https://doi.org/10.1186/s12889-020-09981-y

28. Anteneh ZA, Andargie K, Tarekegn M. Prevalence and Determinants of Acute Diarrhea Among Children Younger Than Five Years Old in Jabithennan District, Northwest Ethiopia, 2014. BMC Public Health. 2017;17(1):1-8. DOI: https://doi.org/10.1186/s12889-017-4021-5

29. Reveles, K. R., Backo, J. L., Corvino, F. A., Zivkovic, M., \& Broderick, K. C. (2017). Fidaxomicin versus Vancomycin as a First-Line Treatment for Clostridium Difficile-Associated Diarrhea in Specific Patient Populations: A Pharmacoeconomic Evaluation. Pharmacotherapy, 37(12), 1489-1497. https://doi.org/10.1002/phar.2049

30. Desmennu, A. T., Oluwasanu, M. M., John-Akinola, Y. O., Oladunni, O., \& Adebowale, A. S. (2017). Maternal Education and Diarrhea among Children aged 0-24 Months in Nigeria. African journal of reproductive health, 21(3), 27-36. https://doi.org/10.29063/ajrh2017/v21i3.2

31. Asioli, D., Aschemann-Witzel, J., Caputo, V., Vecchio, R., Annunziata, A., Næs, T., \& Varela, P. (2017). Making Sense of the "Clean Label" Trends: A Review of Consumer Food Choice Behavior and Discussion of Industry Implications. Food research international (Ottawa, Ont.), 99(Pt 1), 58-71. https://doi.org/10.1016/j.foodres.2017.07.022

32. Kabuya, M. S., Mukuku, O., Van Geertruyden, J. P., Mutombo, A. M., Luboya, O. N., Wembonyama, S. O., \& Lutumba, P. (2019). Maternal Determinants of Diarrhea in Children Under Five in Lubumbashi, Democratic Republic of the Congo. Déterminants maternels de la diarrhée chez les enfants de moins de cinq ans à Lubumbashi, République Démocratique du Congo. Medecine et sante tropicales, 29(3), 273-278. https://doi.org/10.1684/mst.2019.0918

33. Edward, A., Jung, Y., Chhorvann, C., Ghee, A. E., \& Chege, J. (2019). Association of Mother's Handwashing Practices and Pediatric Diarrhea: Evidence from A Multi-Country Study on Community Oriented Interventions. Journal of preventive medicine and hygiene, 60(2), E93E102. https://doi.org/10.15167/2421-4248/jpmh2019.60.2.1088

34. Raza, O., Mansournia, M. A., Rahimi Foroushani, A., \& Holakouie-Naieni, K. (2020). Exploring Spatial Dependencies in the Prevalence of Childhood Diarrhea in Mozambique Using Global and Local Measures of Spatial Autocorrelation. Medical journal of the Islamic Republic of Iran, 34, 59. https://doi.org/10.34171/mjiri.34.59

35. Mihrete TS, Alemie GA, Teferra AS, Access O, Cheng SX, Zhao Y, et al. Prevalence of Diarrhea and Associated Risk Factors in Children Under Five Years of Age In Northern Nigeria: A Secondary Data. Nord J African Stud. 2017;16(1):64-74. DOI: https://doi.org/10.7176/jaas/6005 